اثر كودهاى آلى و كودهاى شيميايى نيتروزنه بر عملكرد و ويزَّىهاى كيفى دو رقم ريحان

مهدى جز گیى'، ويدا جالوى ץ" و وحيد اكبريور

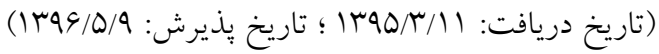

جكيده

افزودن كودهاى آلى كمبوست و ورمى كمبوست به خاره

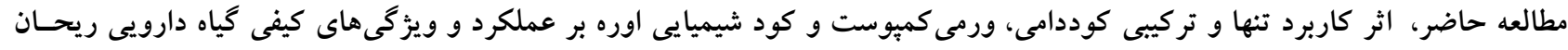

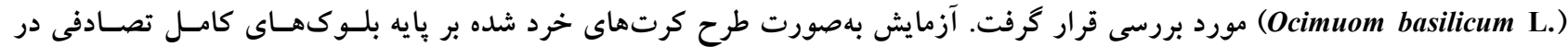

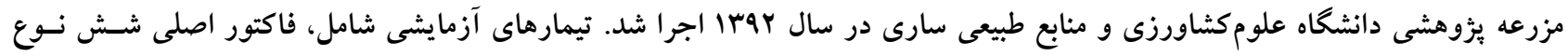

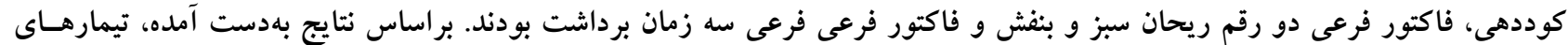

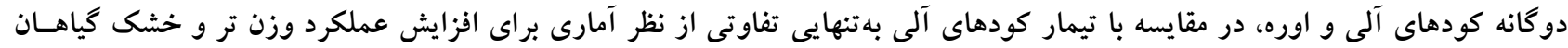

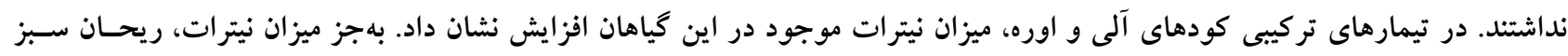

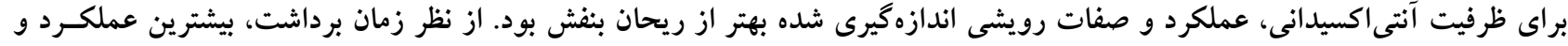

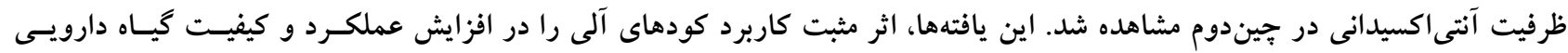

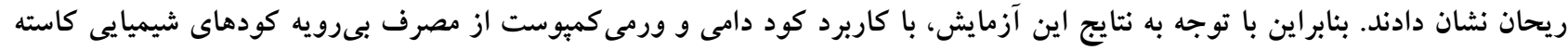

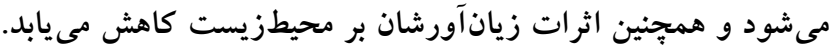

وازههاى كليدى: كود گاوى، كود اوره، ظرفيت آنتىاكسيدانى، نيترات، ورمى كميوست گاوى

ا، r و rا. بهترتيب دانشآموخته كارشناسى ارشد و استادياران، كروه باغبانى، دانشگاه علوم كشاورزى و منابع طبيعى سارى

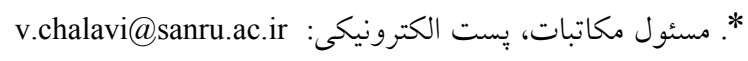


است كه در كميوستهاى شهرى وجود دارد. همجِنسين، منشـاء

مقدمه

سلولز موجود در كود كاوى از كاه غلات است كه در مقايسه بـائا

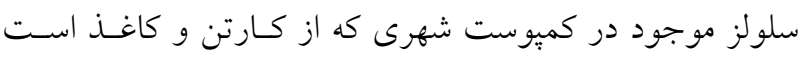

راحتتر و سريعتر تجزيه مىشود (TD).

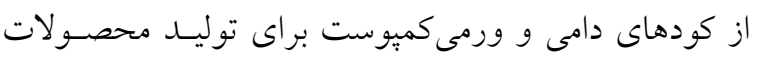

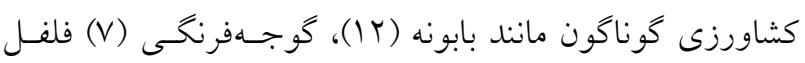

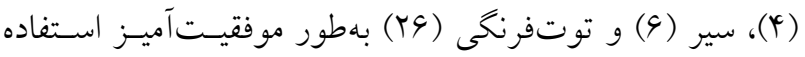

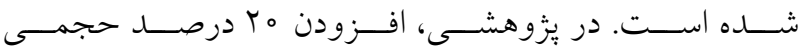

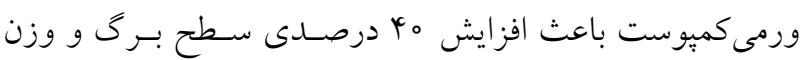
خشى كوجافرنكى و بهبود خصوصسيات رشـدى گيساه گرديــ (Y). كاربرد ورمى كميوست بر روى كياه ريحان باعـث افزايش

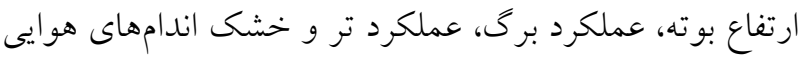

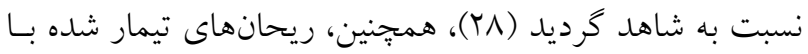

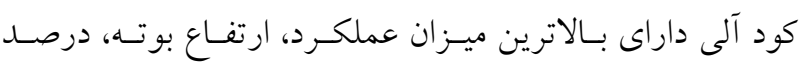
اسانس، وزن تكبوته، تعداد و سطح برگ بودند (11). كودهاى آلى با وجود تمامى اثرات مفيد و كوناكونى كه بـر

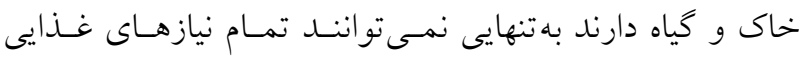
كياهان را برآورده سازند. علاوهبر اين، بدون استفاده از كودهاى

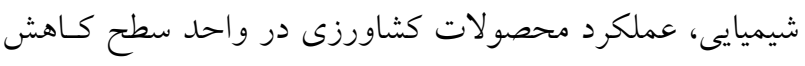
و هزينههاى توليد اين محصولات افزايش خواهند يافـت (TV).

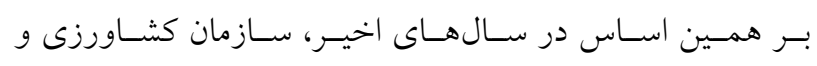

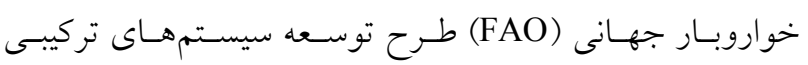

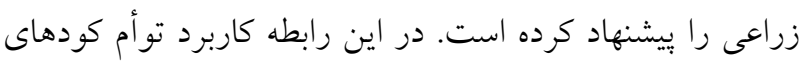

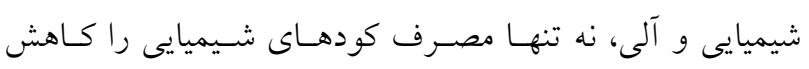

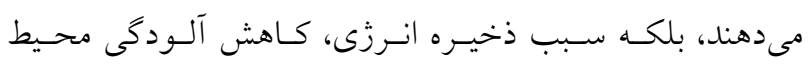

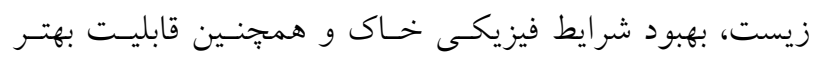

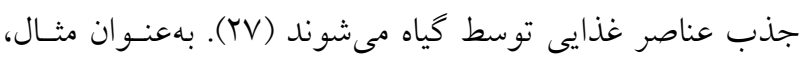

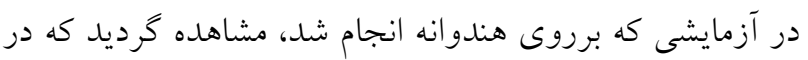
تيمارهاى كود مرغى در تركيب با كميوست و كودهاى شيميايى

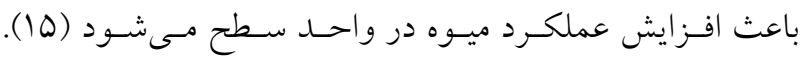

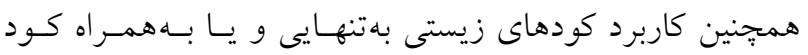
شيميايى سبب بهبود كميت و كيفيت ريحان كرديد (Tr).

استفاده درست از منابع مختلف كودى مى توانــد اثـرات قابـل ملاحظهاى برعملكرد و نيز كيفيت محصولات داشته باشـــ (IN).

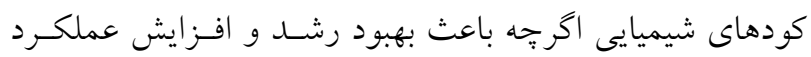

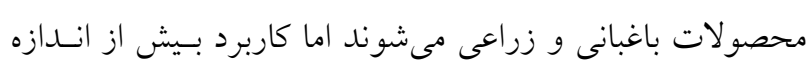

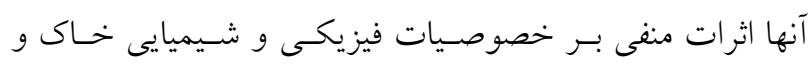

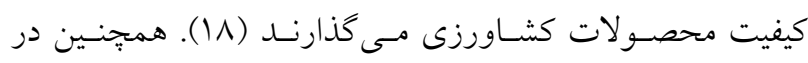

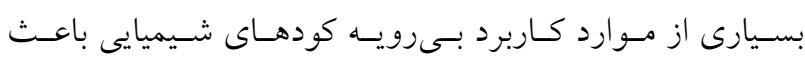

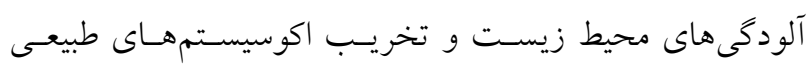

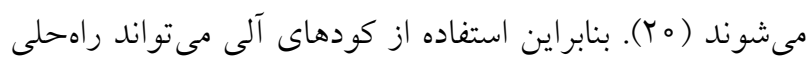

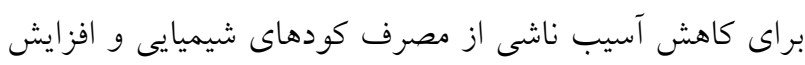

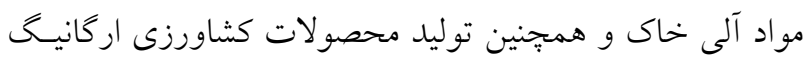

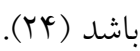
كودهاى آلى داراى تنـوع بسـيار زيـادى هسـتند. در حسال

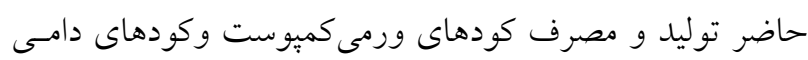

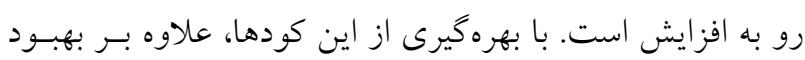

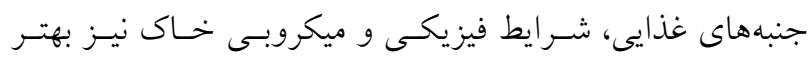

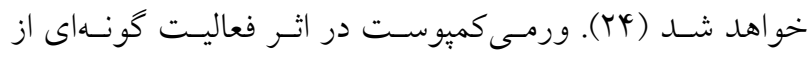
كرمهاى خاكى بر روى مواد آلى موجود در خاك توليد مىشـود

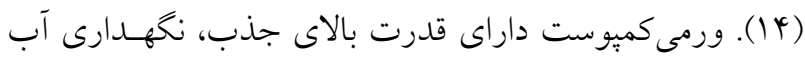
و عناصر غذايى است و سبب افزايش تخلخل و در نتيجه تهويه

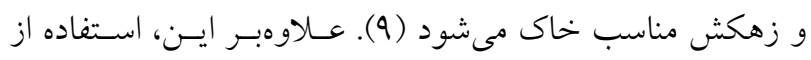

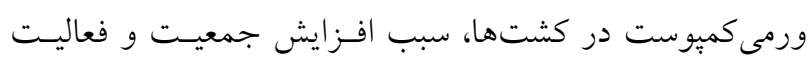

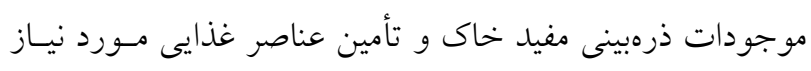

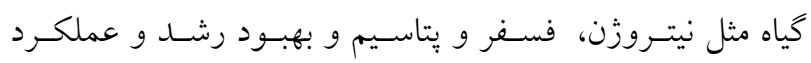

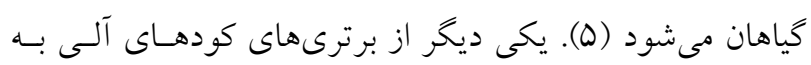

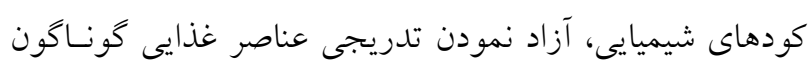

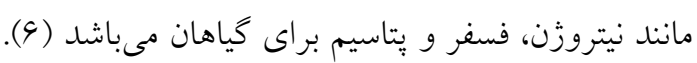

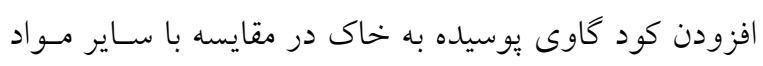

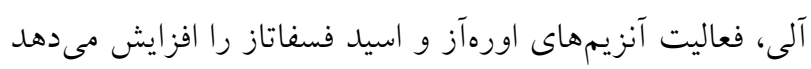

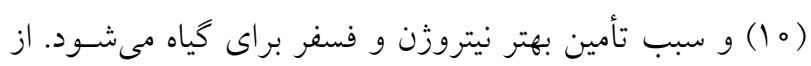

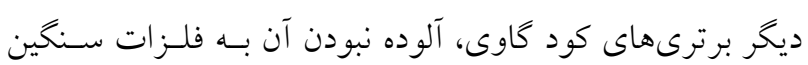


بيش از اجراى آزمايش، نمونه خـاك جهـت تجزيـه خصوصسيات

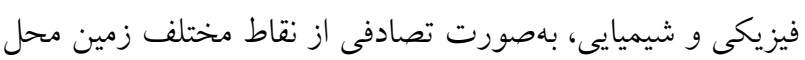

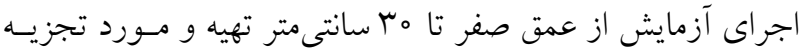

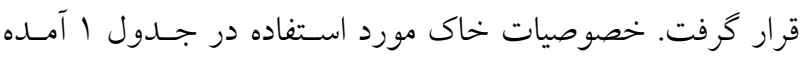

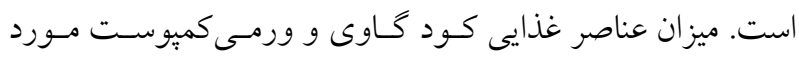
استفاده نيز اندازهيرى شد (جدول Y Y). با توجه به خصوصسيات فيزيكى و بيوشسيميايى خـاك محل آزمايش (جدول ()، تيمارهـاى كـودى آزمـايش انتخـاب شــندئ.

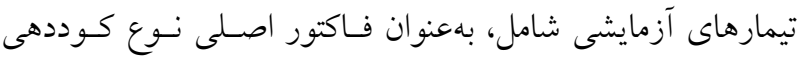
شامل 9 تيمار ورمى كميوست يا كود كاوى هب تن در هكتـار، 10

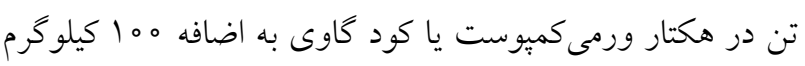

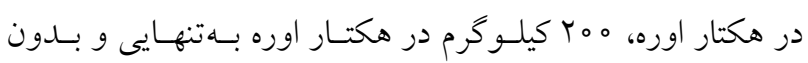

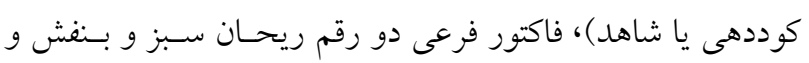

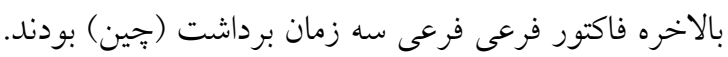

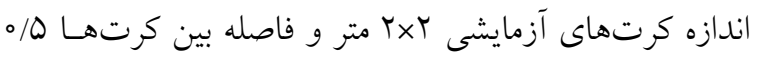
متر و فاصله بين بلوكها يكى متر درنظر كرفته شد. كـود خـاوى و ورمى كميوست يك ماه يِي از كاشت به زمين اضافه شـدند و تـا عمق ها سانتى متر با بيل دستى با خاك مخلوط كرديدند. در سـهـ

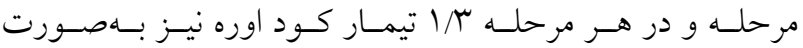
محلولٍياشى (مرحله اول در تخند روز بعد از نشـاءكـارى، مرحلـه

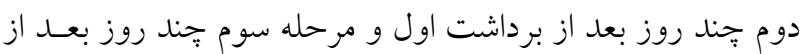
برداشت دوم) به كَاهان داده شد. قبل از كاشت گياهـان در زمهـين

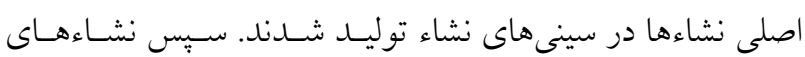

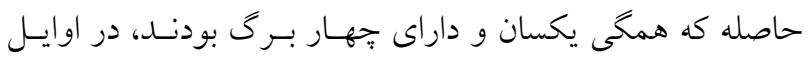

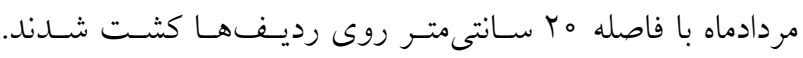

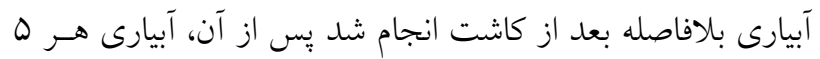

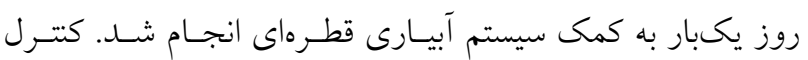

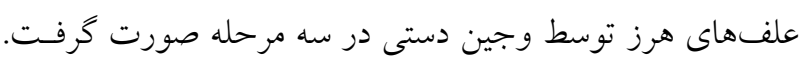
برداشت بهصورت سه زمان برداشت، در هـر بـار بـــش از زمـان

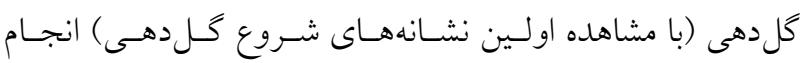
كرفت. بيش از هر برداشت، ها بوته از هر تيمـار در هـر تكـرار

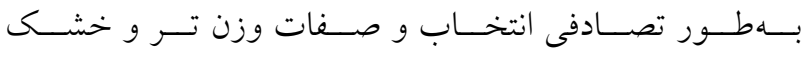

ريحـان (Ocimuom basilicum L. يكى از كياهـان مهـم

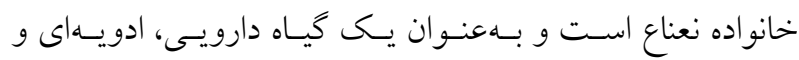

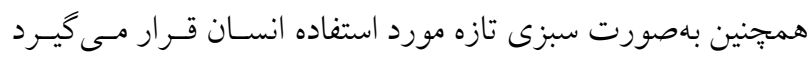

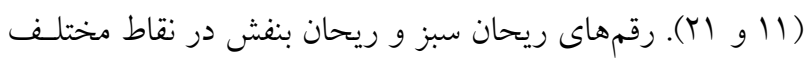

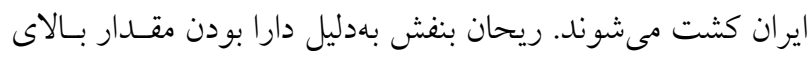

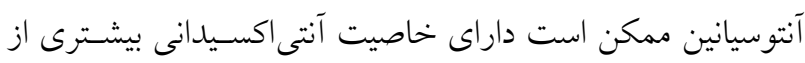

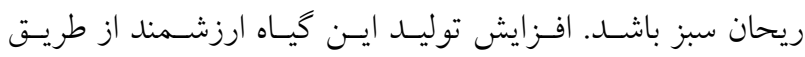

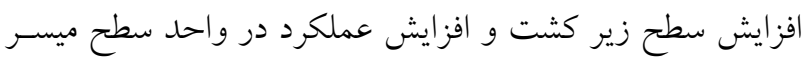

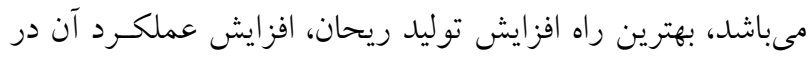

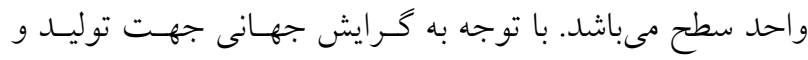

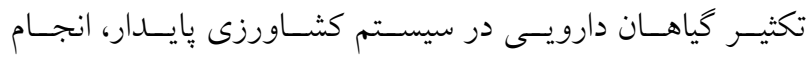
يُزوهش هايى براى كاهش مصرف كودهاى شسيميايى، كـه كـاربرد

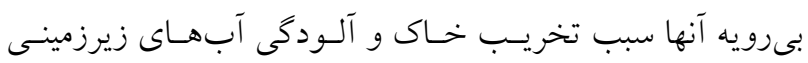

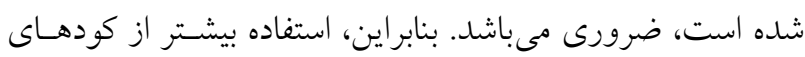

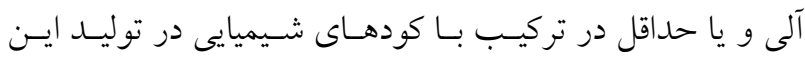

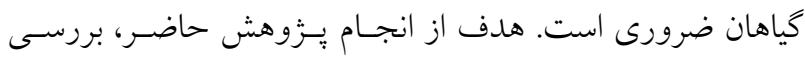

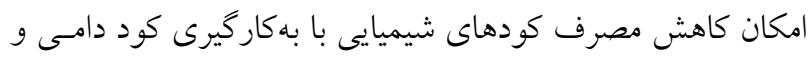

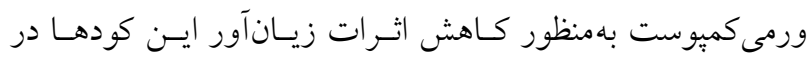

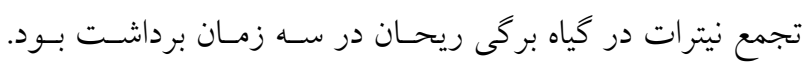

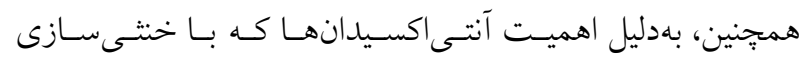

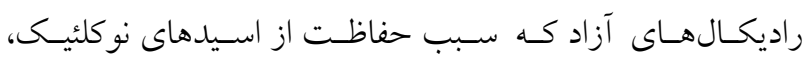

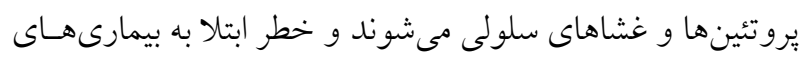

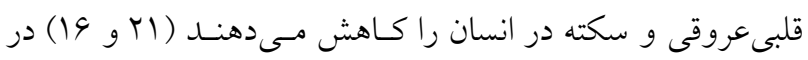

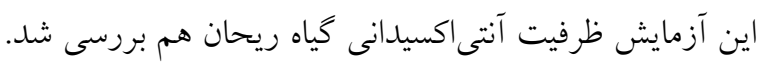

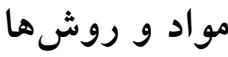

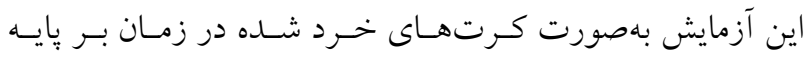

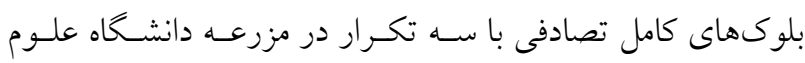

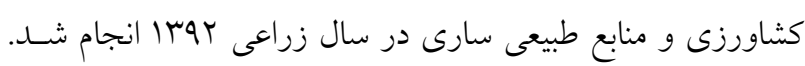

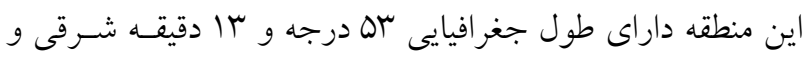

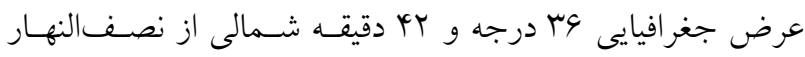
كرينويج و ميانكين ارتفاع 19 متر از سطح دريا واقع شـــه اسـت ودئ. 
جدول ا. خصوصيات فيزيكى و بيوشيميايى خاك

\begin{tabular}{|c|c|c|c|c|c|c|c|c|c|}
\hline \multirow{2}{*}{ بافت } & رس & سيلت & شن & يتاسيم * & فسفر * & نيتروزن كل & كربن آلى & \multirow{2}{*}{ اسيديته } & \multirow{2}{*}{$\begin{array}{l}\mathrm{EC} \times 10^{r} \\
(\mu \mathrm{mho} / \mathrm{cm})\end{array}$} \\
\hline & & $(\%)$ & & \multicolumn{2}{|c|}{$(\mathrm{ppm})$} & \multicolumn{2}{|c|}{$(\%)$} & & \\
\hline سيلتى رسى & 19 & 41 & 10 & $Y \Delta 1$ & $r \Lambda / T^{*}$ & O/MY & $r / 91$ & V & - $/ 94$ \\
\hline
\end{tabular}

\begin{tabular}{|c|c|c|c|c|c|c|c|c|c|}
\hline روى* & آهن & منغنز * & يتاسيم * & فسفر * & نيتروزن كل & كربن آلى & \multirow{2}{*}{ اسيديته } & \multirow{2}{*}{$\begin{array}{c}\mathrm{EC} \times 10^{r} \\
(\mu \mathrm{mho} / \mathrm{cm})\end{array}$} & \multirow{2}{*}{ كودهاى آلى } \\
\hline \multicolumn{3}{|c|}{ (ppm) } & \multicolumn{4}{|c|}{$(\%)$} & & & \\
\hline T\&9 & Y००० & $T Q_{\circ}$ & $r / 9$ & $T / V$ & $1 / 09$ & r。 & $V / I$ & $V / T Q$ & ورمى كميوس ست \\
\hline MTI & rVo。 & MAT & $1 / 4$ & $T / T^{c}$ & $1 / T r$ & $M Y / Y I$ & $V / T I$ & $Y / \circ V$ & كود كاوى \\
\hline
\end{tabular}

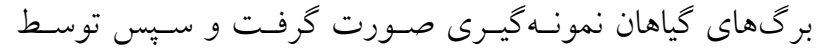
نيتروزن مايع يودر و در دماى مr - درجه سـانتى گـراد نخهـدارى شدند. سيس به ه/ه گرم از بافتهاى يودر شده با نيتروزن مـايع، ه ميلىليتر متانول هم درصد اضافه شد. نمونههاى گياهى يسس از همزدن با استغاده از دستخاه ورتكـس، بـهمــات يـك سـاعت در

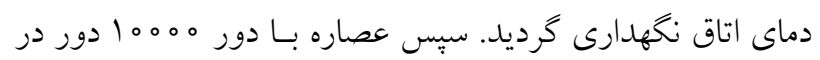
دقيقه بهمدت ه ا دقيقه سانتريفيوز گرديد. براى قرائـت نمونسههـا

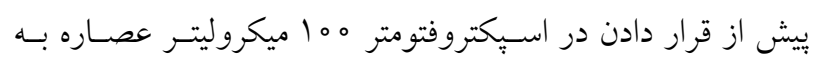

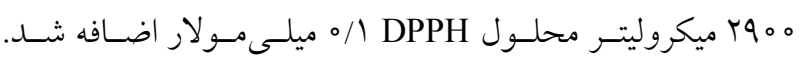
مخلوط حاصل يس از افزودن DPPH ورتكس شده و يـس از ها دقيقه در دماى اتاق و تاريكى، كاهش ميزان جذب در طول مـوج

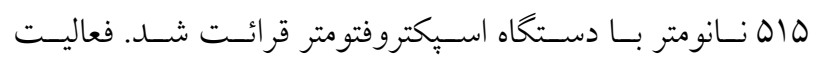
خنىى كنندكى راديكال DPPH توسط عصاره كه معيـارى از ميـزان فعاليت آنتىراديكالى عصاره است، مطابق رابطه ا محاسبه گرديد. RSA $\%=\frac{\text { ODcontrol }- \text { ODsample }}{\text { ODcontrol }} \times 1 \circ 。$

در اين رابطه OD control جذب كنتـرل، OD sample جـــب نمونه و RSA فعاليت حذف كنند

\section{تعيين ميزان نيترات گياه}

ميزان نيترات در نمونه خشى كياهى به روش كالرىمترى يسس
اندامهاى هوايى گياه، تعـداد شـاخههـاى جــانبى، ارتفــاع بوتـه،

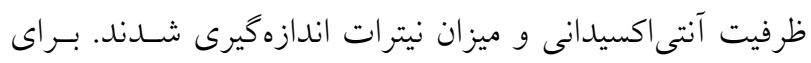
محاسبه عملكرد نهايى اندامهاى هـوايى در هـر كـرت، يـس از

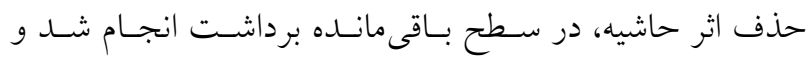
عملكرد تر و خشك اندامهاى هوايى گياه تعيين گرديد.

اندازهيرى ارتفاع، تعداد شاخه جانبى و وزن تر و خشى ارتفاع گياهان در سه برداشت با استفاده از متر اندازهذيرى شـد. تعداد شاخههاى جانبى با شمارش تعداد شاخههاى رشـد كـرده در هر بوته بهدست آمد. براى اندازهذيرى وزن تـر گيـاه در هـر بوته، نمونهها به تفكيك برى و ساقه به كمـك تـــازو ديجيتـال

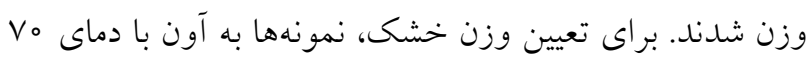

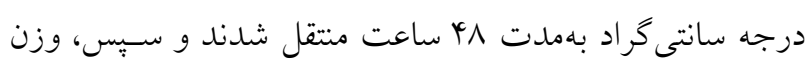
خشك نمونهها تا دقت دو رقم اعشار به كمك ترازو تعيين شد. تعيين ظرفيت آنتى اكسيدانى ظرفيت آنتى اكسيدانى با روش احيـا راديكـال آزاد (9 (1) بـا كمسى

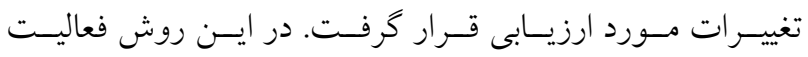
حذف كنندكى راديكالى (RSA) به كمـك r، r- دى فنيـليكريـل

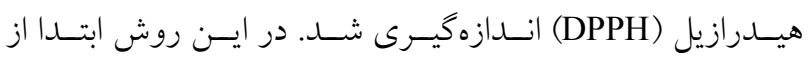


تر و خشك كل انــامهــاى هـوايى بوتـه بسـيار معنسىدار بـود (جدول r). وزن همه اندامهاىهاى تر و خشك هـو ايى ريحـان در كودهاى آلى و شيميايى بهطـور معنسىدارى بيشـتر از تيمـار

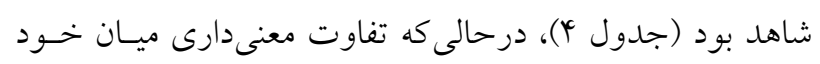
اين تيمارهاى كودى آلى و شـيميايى ديــه نشـــ. بـراى نمونسه، شاهد نزديك به بر/ كمتر از ميانخين ه تيمار كودى ديخر، وزن تر برگ توليد كرد. جين هم اثر بسيار معنسىدارى بـر وزن تـر و

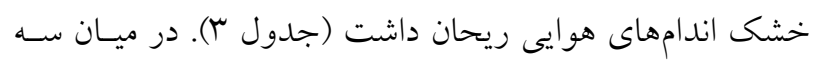
برداشت، جين دوم بهطور معنى دارى توليد بيشترى نسبت به دو جين ديخر داشت. بيشترين و كمترين مقـدار وزن تـر و خشـى برى در بوته و كل اندام هـو ايیى بـهـترتيـب در جهـين دوم و اول

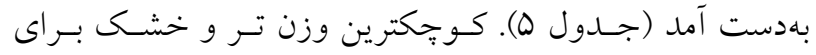
زمان برداشت اول انتظار مىرفت، جهون در اين مرحلـه، گياهـان فقط يك ساقه اصلى داشتند. پِ از بريدن ساقه اصلى در زمـان

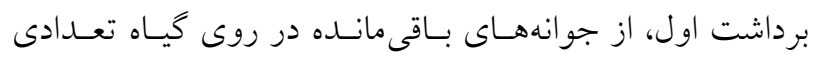
ساقههاى جانبى در برداشتهاى دوم و سـوم توليـد شـدند. در مورد بيشترين وزن تر و خشك در برداشت دوم، احتمالاً شرايط بهينه آب و هوايى، مانند دماى مناسـب هـوا و تعـداد روزهـاى آفتابى در زمان برداشت دوم سبب شد كه وزن تر و خشـى در اين برداشت بيشتر شود. اثر رقم بر وزن تر و خشك انـدامهـاى هوايى ريحان بسيار معنى دار بود (جـدول م). در ميـان دو رقـم

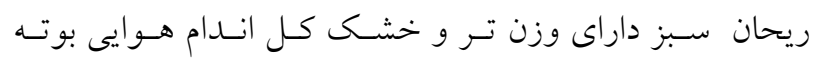
بيشترى نسبت به ريحان بنفش بود (جدول و). برهمكنش كود و رقم و برهمكنش كود و جين، بهجز سـاقه جانبى و ارتفاع ساقه، اثرى بر وزن تر و خشك اندامهاى هوايى نداشتند، درحالى كه برهمكنش رقم و جين بــر همـه انـدامهـاى هوايى اثر بسيار معنىدارى داشت (جــدول ب). بهتــين تركيـب رقم و جين براى وزن تر و خشك اندامهاى هوايى براى ريحان سبز و جين دوم بهدست آمد (جدول ^). بهتـر بـودن جهـين دوم نسبت به دو جين ديخر شايد به اين دليل است كه در زمان رشد كياه براى جين دوم، دماى هــواى تابسـتان كـاهش يافتـه بـود و شرايط محيطى بهينهاى بــراى رشــ گياهـان فـراهم شـــه بــود.
از احياء (r) اندازهذيرى شد. در ايسن روش يـس از جمـع آورى

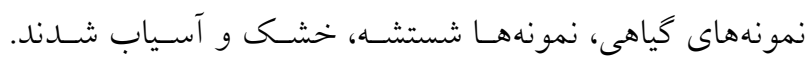

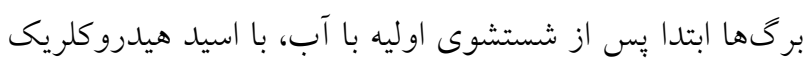

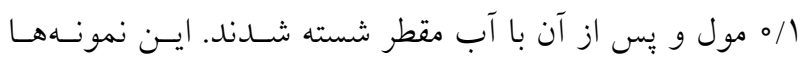

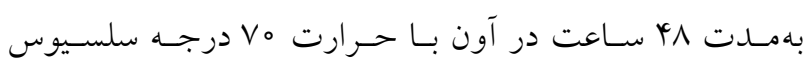
خشك شدند و سبس آسياب شد و از الك ه/ه ميلىمترى عبور

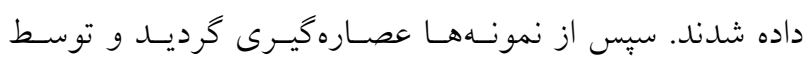

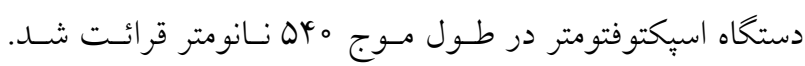
همجِنين ميزان نيتروزن نيتراتسى ( برحسب ميلى گرم در كيلو گرم (يى يىام) از رابطه ب محاسبه شد. 1००/D.M $\times 0 \circ / \mathrm{w} \times(\mathrm{a}-\mathrm{b})$

در اين رابطه a عدد قرائت دستخاهى بـراى نمونـه، b عـدد

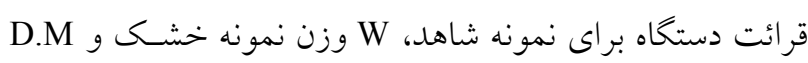
درصد ماده خشك گياهى است. اندازهيرى مقدار اسانس براى تهيه هر نمونه، ابتدا •ه گرم برى تر بهصورت تصـادفى از

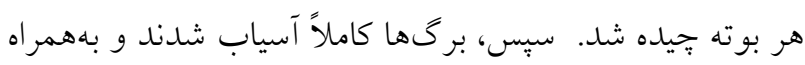
ه م ميلى ليتر آب درون بالن يك ليتـرى جـا كرفتنـد. اسـتخراج اسانس نمونهها به كمك دستخاه كلونجر بهمدت بأ ساعت انجـام

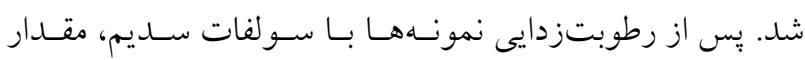

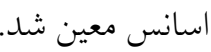
تجزيه و تحليل آمارى دادهها با اسـتفاده از نـرمافـزار آمـارى ســ SAS برداشت در طول آزمايش، اطلاعات با استفاده از طرح كرتهاى

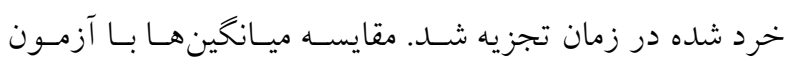
SNK و در سطح احتمال ه درصد انجام شد.

\section{نتايج و بحث}

وزن تر و خشك برى و ساقه در بوتسه و وزن تـــ و خشـى كل اندامهاى هوايى بوته اثر تيمار كودى بر وزن تر و خشك برى و ساقه در بوته و وزن 


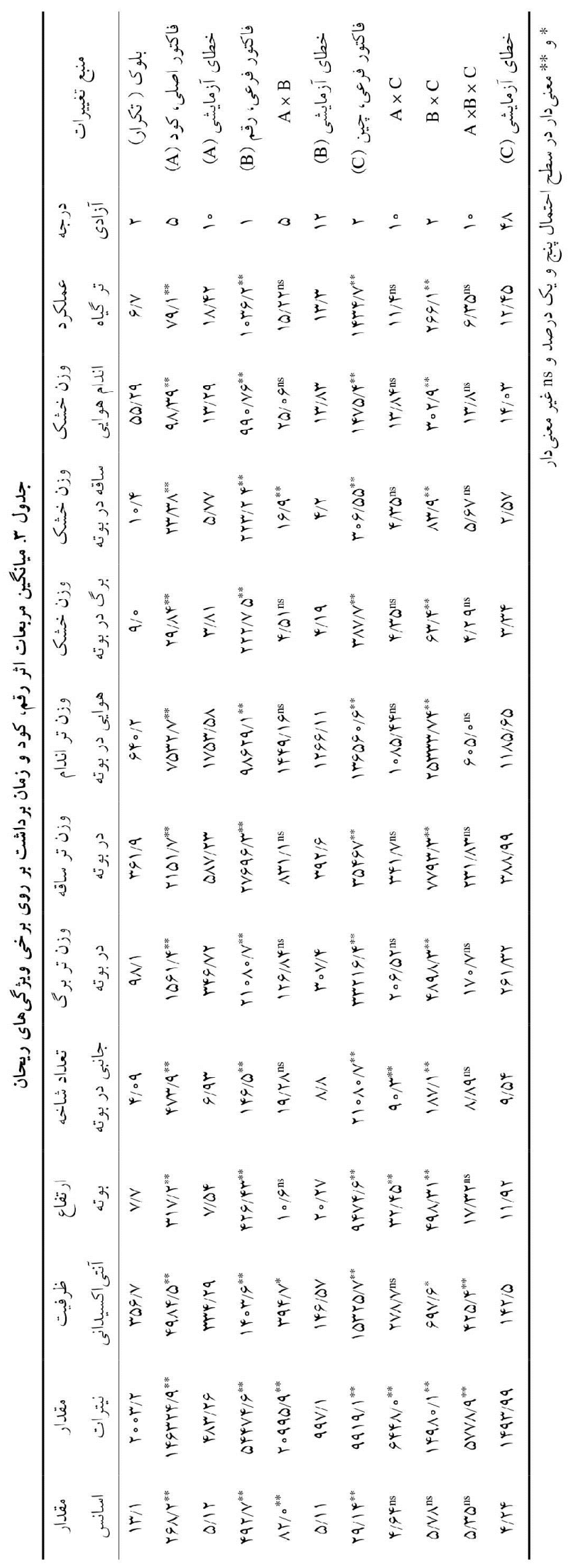




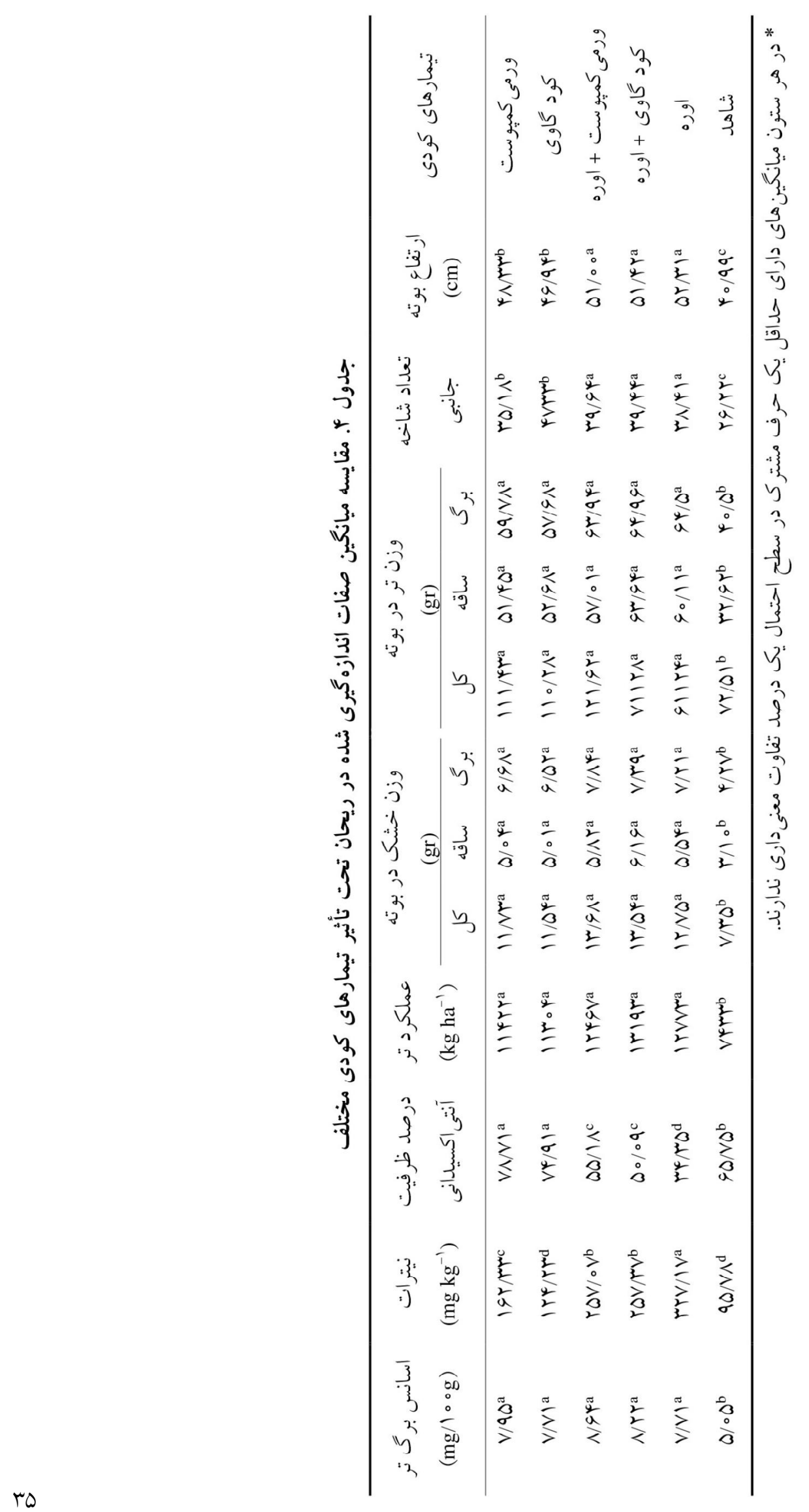



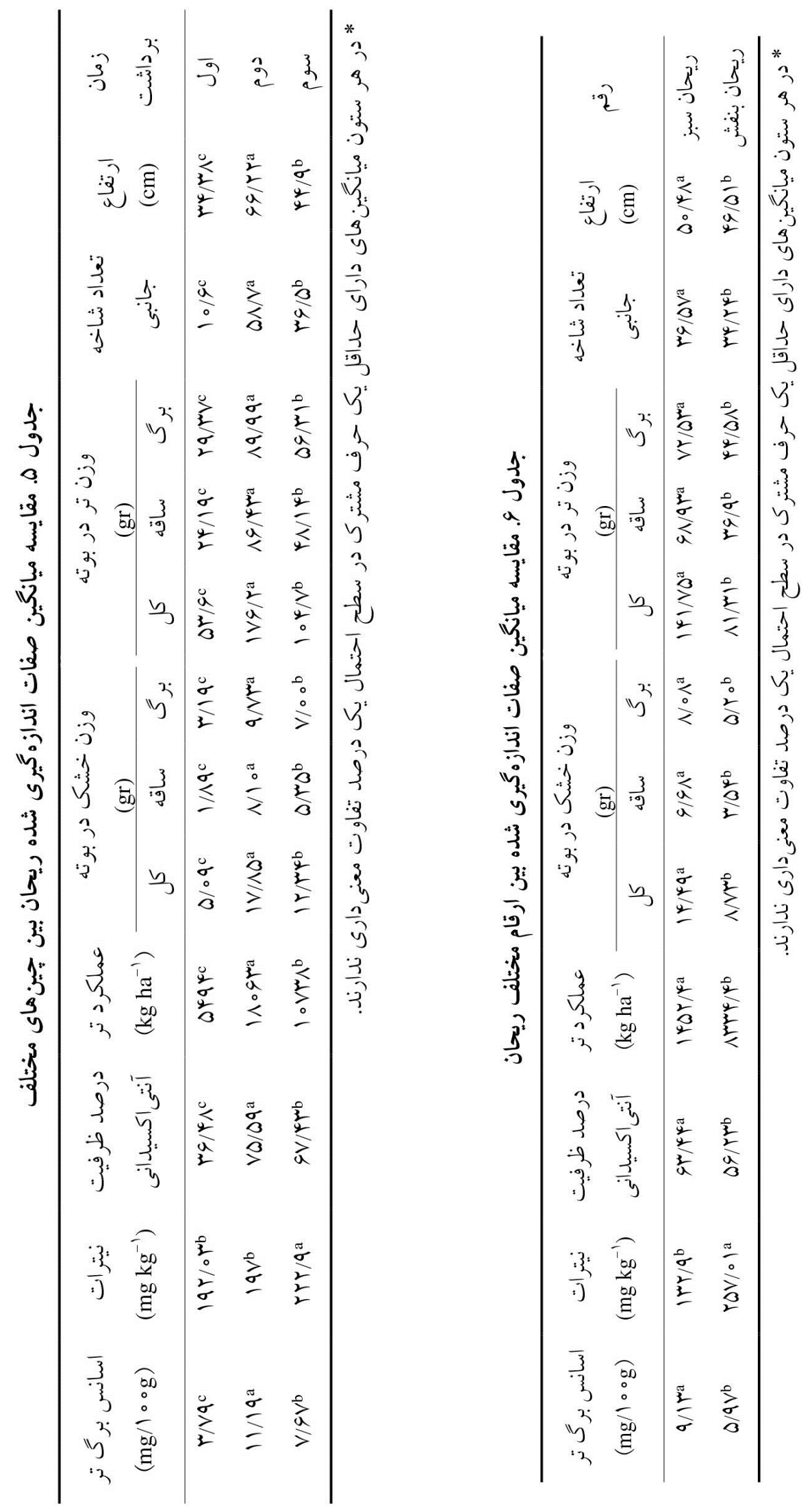


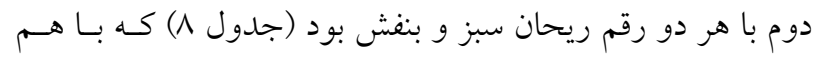

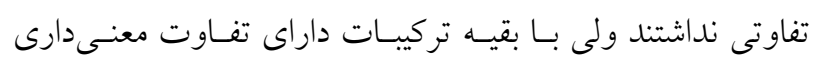

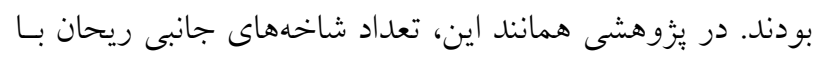

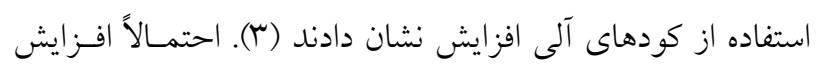

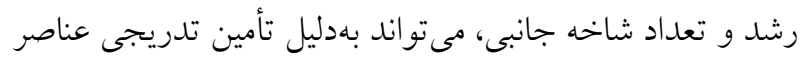

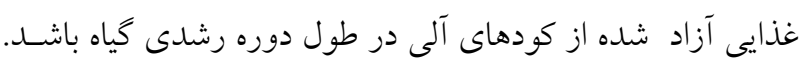

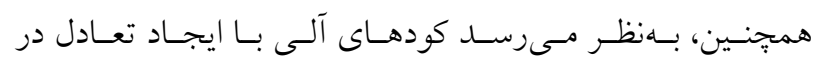

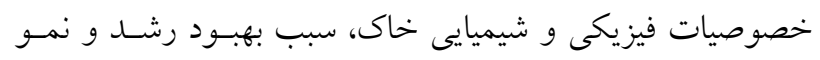

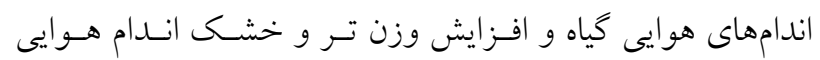

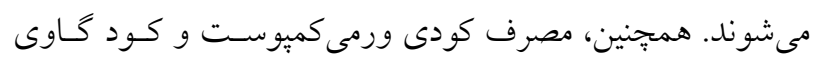

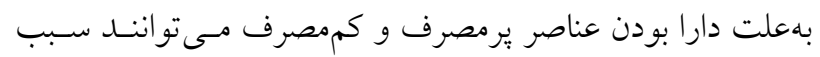

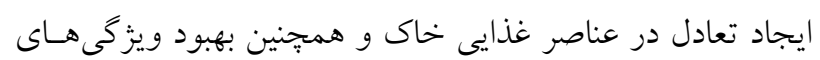

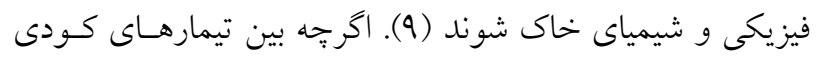

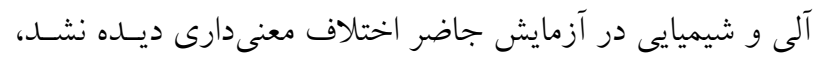

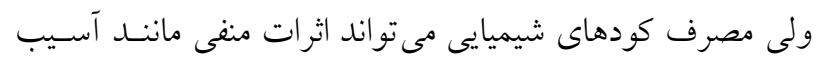

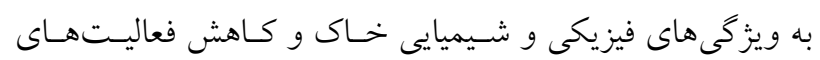

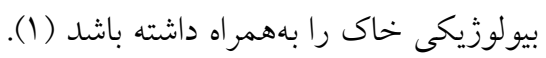

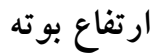

تيمارهاى كودى، رقم، جين و برهمكنش جين با كود و رقم اثـر

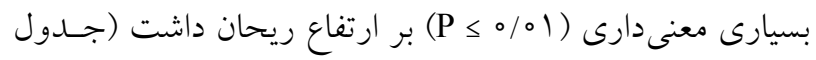

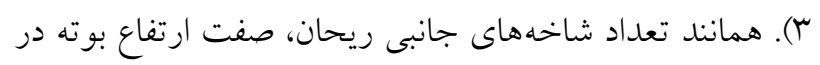

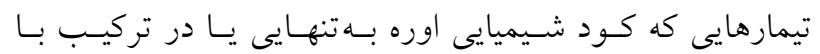

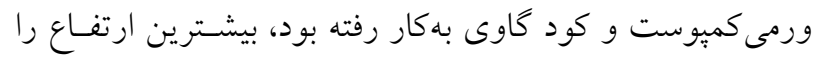

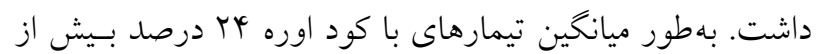

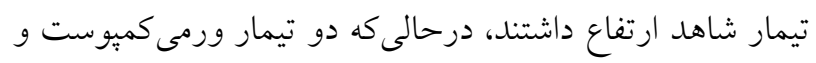

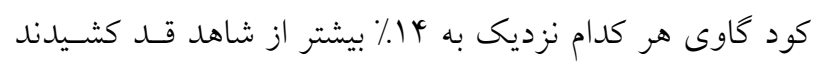

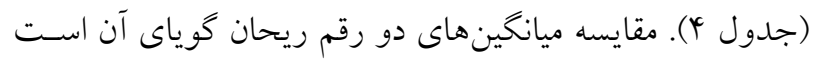

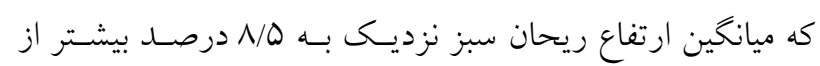

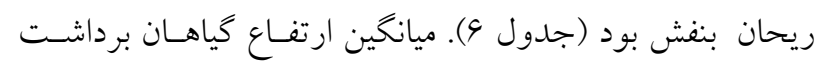

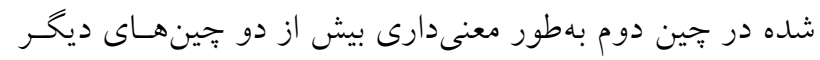

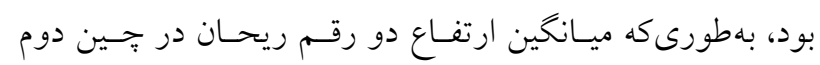

تعداد شاخههاى جانبى

تيمار كودى، رقم، جين و برهمكنش هاى كود و جهين و رقـم و و

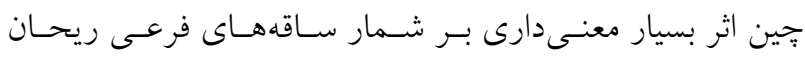

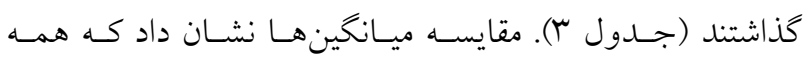
تيمارهاى كودى نسبت به شاهد سبب افزايش تعداد ساقه فرعى

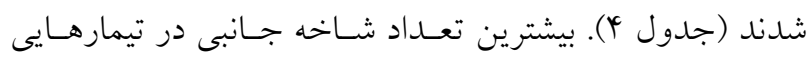

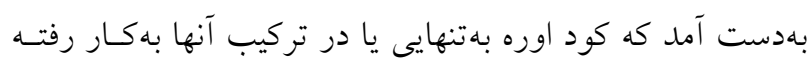

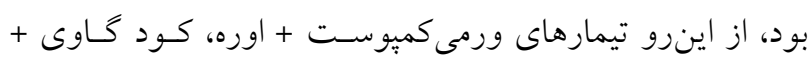

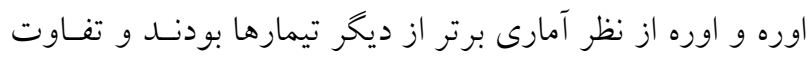

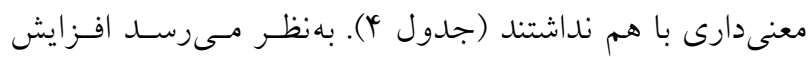

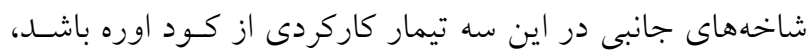

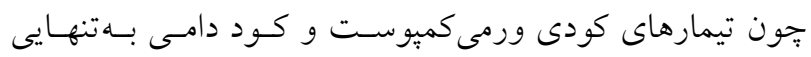

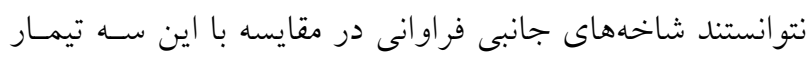

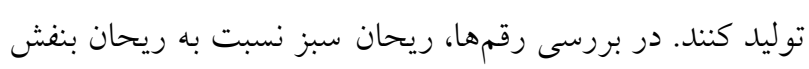

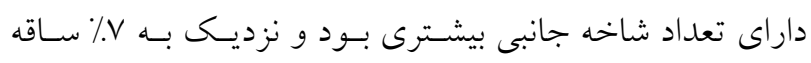

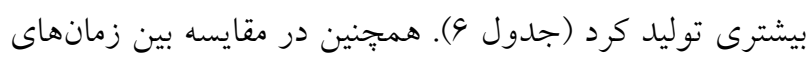

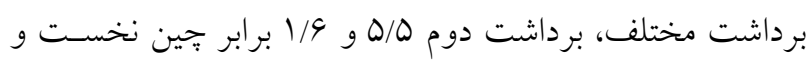

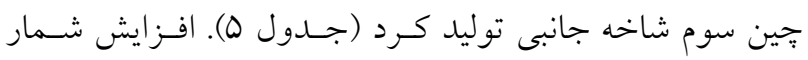

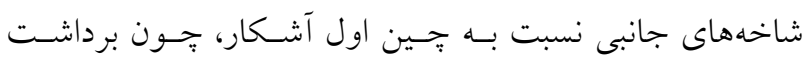

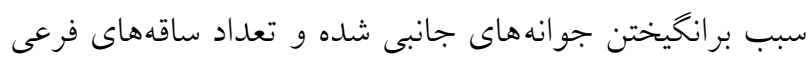

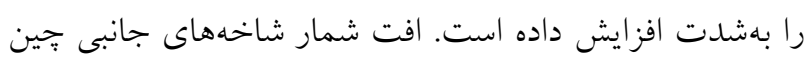

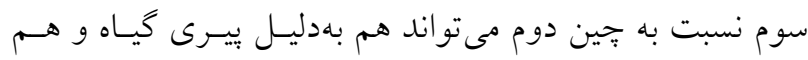

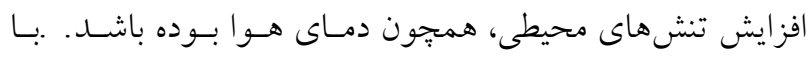

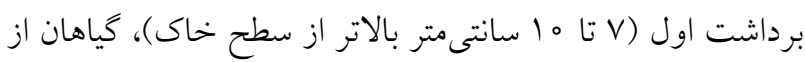

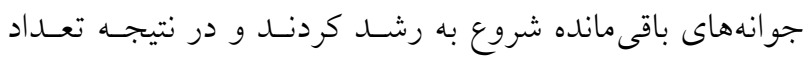

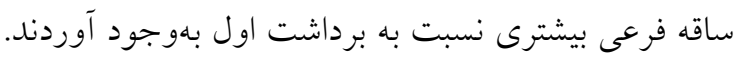
برهمكنش تيمارهاى زمان برداشت و كود براى تعـداد شـاخه.

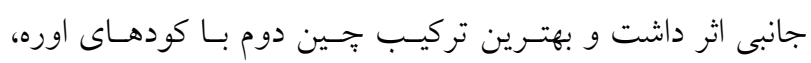

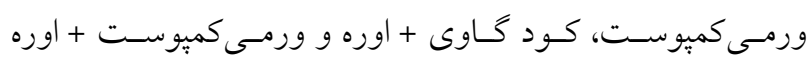

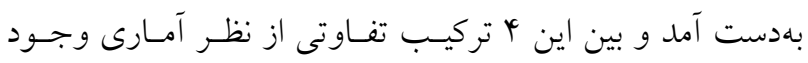

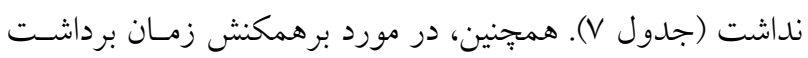

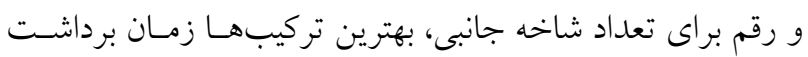


جدول V. مقايسه ميانگين برهمكنش كود × زمان برداشت (جين) ريحان

\begin{tabular}{|c|c|c|c|c|c|}
\hline $\begin{array}{l}\text { مقدار نيترات } \\
\left(\mathrm{mg} \mathrm{kg}^{-1}\right)\end{array}$ & درصد ظرفيت آنتى اكسيدانى & فرعى تراد ساقه & $\begin{array}{c}\text { ارتفاع بوته } \\
\text { (cm) }\end{array}$ & جين & تيمارهاى كودى \\
\hline$q \circ / \wedge \mu^{f}$ & ry/Mrd & $\mathrm{V} / \mathrm{V} \boldsymbol{H}^{\mathrm{g}}$ & ro/fre & \multirow{6}{*}{ اول اول } & شاهد \\
\hline$Y \wedge \Lambda /\left.D\right|^{b c}$ & $19 / 11^{e}$ & $11 / \wedge^{f}$ & $r N / Y l^{d}$ & & اوره \\
\hline $191 / 99^{\mathrm{e}}$ & $\Delta \varphi / 4 \varphi^{c}$ & $\mid r / \mu \mu_{f}^{f}$ & $\mathrm{rV} / \mathrm{N}^{\mathrm{d}}$ & & ورمى كميوست \\
\hline $\mid Y N / \circ \wedge^{e}$ & $<q / q^{q c}$ & $10 / 94^{\mathrm{f}}$ & $m / 9 \wedge^{d}$ & & كود كاوى \\
\hline rDG/TYcd & $Y \Lambda / \circ \wedge^{d}$ & $11 / \mu^{f}$ & $M y / Y^{d}$ & & كود گاوى + اوره \\
\hline rYG/4Yd & $\mathrm{m} 1 / 9 \Lambda^{\mathrm{d}}$ & $\mid r / \mu^{\mathrm{f}}$ & $r \varphi / 0 \mu^{d}$ & & ورمى كيوست + اوره \\
\hline$\Lambda \mathrm{Q} / \circ V^{\mathrm{e}}$ & $91 / 4 \mathrm{cma}^{2}$ & $\kappa \mu / / \Lambda^{c}$ & $91 / 01^{b}$ & \multirow{6}{*}{ دوم } & شاهد \\
\hline$r q \circ / r^{b}$ & $\mathrm{rq} / \Lambda \kappa^{\mathrm{cdd}}$ & $q \mu / V^{a}$ & $9 q / Y Y^{4 a}$ & & اوره - تاون \\
\hline $19 \% / 01 \mathrm{e}^{\mathrm{e}}$ & $q \circ / 9 V^{a}$ & $41^{\mathrm{a}}$ & $9 \pi / 99^{b}$ & & ورمى كميوست \\
\hline $14 \circ / 90^{\mathrm{e}}$ & $91 / r V^{a}$ & $\Delta Q / Y I^{b}$ & $G Y / \mathcal{G} \Delta^{\mathrm{b}}$ & & كود گاوى \\
\hline$r V \circ / T \Delta^{b c}$ & $94 / 19^{b}$ & $94 / 9 a$ & $\vee \backslash / \Delta \wedge^{a}$ & & كود گاوى + اوره \\
\hline$r \mu \Delta / q V^{c}$ & $V Y / / V^{b}$ & $G 4 / V^{a}$ & $\varphi \wedge / \wedge \varphi^{a}$ & & ورمى كيوست + اوره \\
\hline $111 / 4 f_{f}^{f}$ & $V I / Y^{c b}$ & rV/VGe & rG/० & \multirow{6}{*}{ سوم } & شاهد \\
\hline$r \circ r / 99 \mathrm{a}$ & $\hat{c r} / \varphi_{c}$ & $r q / q \mu_{c}$ & $4 q / 4 \Lambda^{c}$ & & اوره \\
\hline $194 / 99 e$ & $\Lambda \mathrm{V} / \mathrm{V}^{\mathrm{a}}$ & rY/Y & $\mathrm{cr} / g \mu_{\mathrm{c}}$ & & ورمى كميوست \\
\hline $1 \circ r / 9 \Delta^{f}$ & $\Lambda \psi / \circ \varphi^{a}$ & $r Y / \Delta \Delta^{d}$ & $\mu y / \psi^{c c}$ & & كود گاوى \\
\hline$Y Y Q / D I^{\mathrm{cd}}$ & $\Delta Q / \mu Y^{c}$ & $\leftarrow r / \Delta^{c}$ & YN/YGc & & كود كاوى + اوره \\
\hline$\mu \circ q / \circ \wedge^{b}$ & $G Y / V b c$ & $K Y / \circ D^{c}$ & $\mathrm{FV} / \mathrm{G}^{\mathrm{c}}$ & & ورمى كيوست + اوره \\
\hline
\end{tabular}

و كود كاوى با اوره بهدليـل استفاده از كـود اوره در هـر زمـان

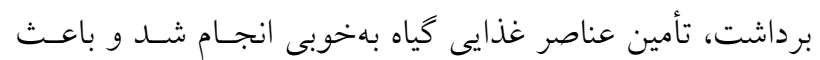

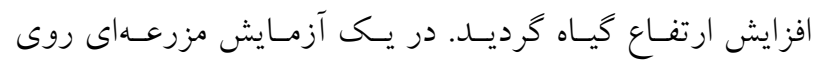

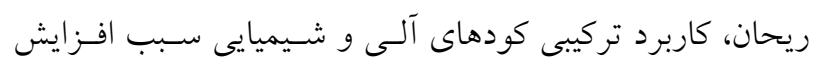

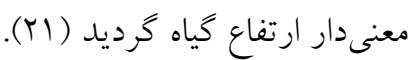

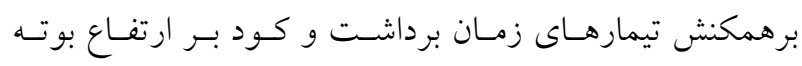

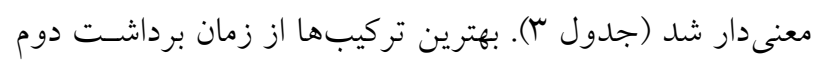

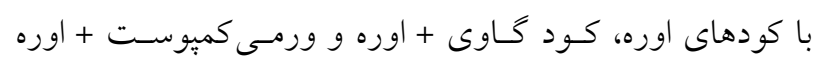

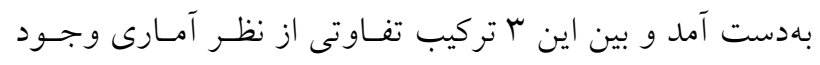

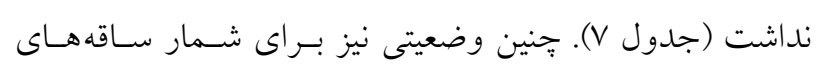

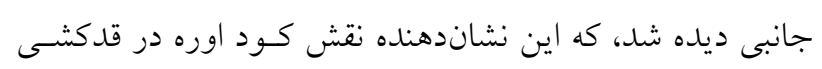

بهترتيب \&9 و مه درصد بيشتر از جين هاى نخست و سوم بـود

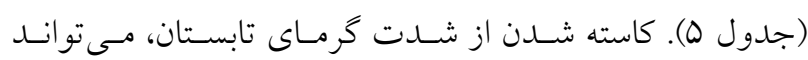

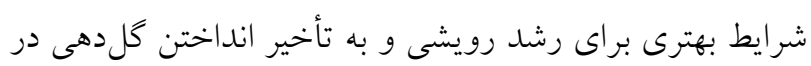

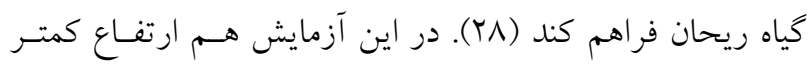

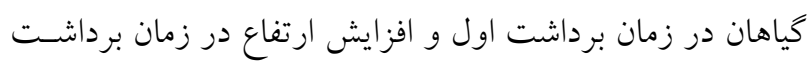

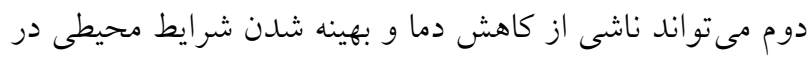

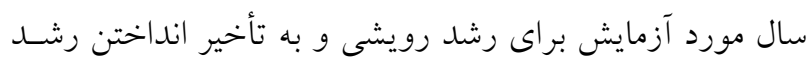

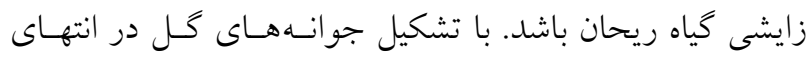

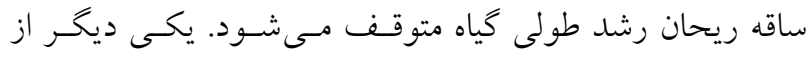

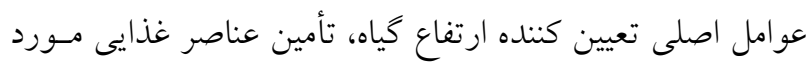

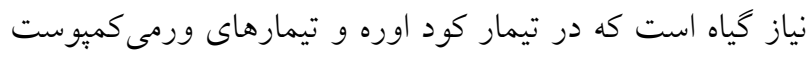




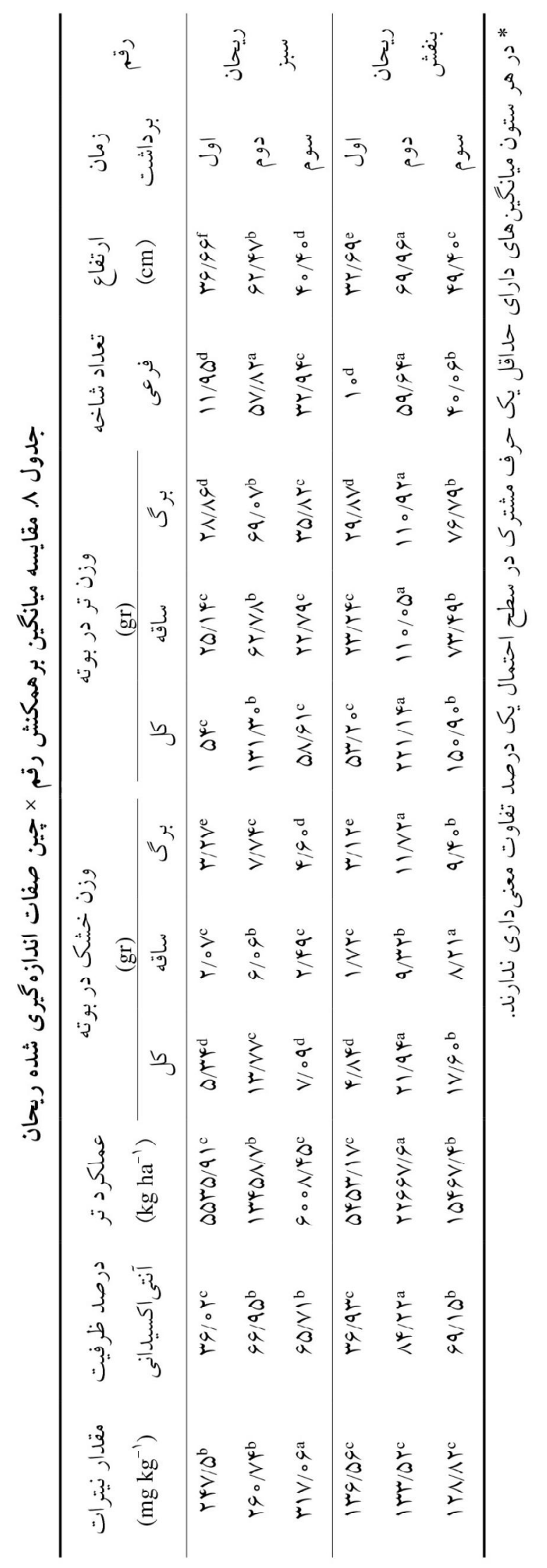


هم خواهند شد (YY). از طـرف ديخـر، كودهـاى آلى بـهدليـل

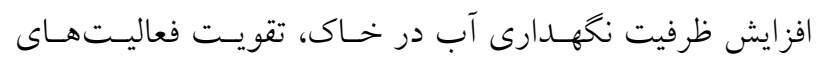

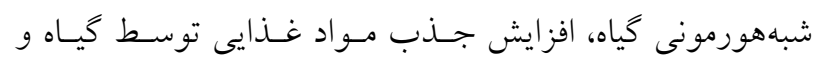

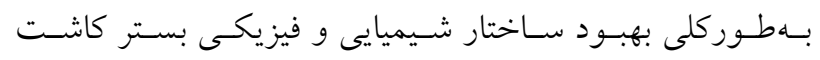

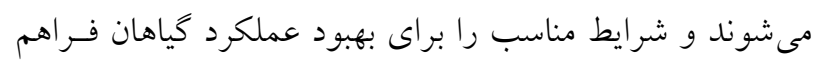

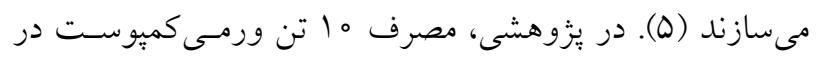

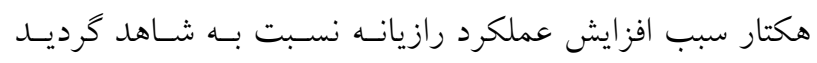

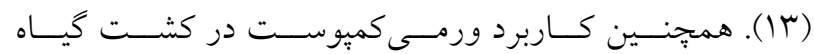
كوجهفرنخس، عملكـرد ايسن محصـول را بـهــرز جشـميخيرى

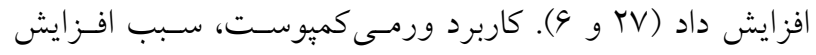
عملكرد بابونه (^) و سير (9) شد. بهطوركلى، مصرف كودهـاى زيستى مانند ورمى كميوست باعث افزايش كيفيـت و بايسـارى

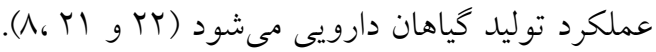
همجون ديخر اندامهاى هـوايى عملكـرد كـل در جـين دوم

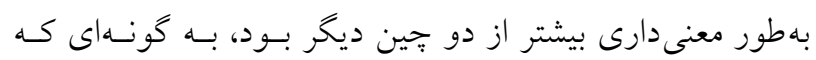

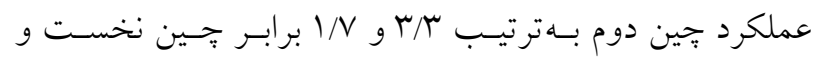
جين سوم بود (جدول ه ه). عملكــرد كـل در رقـم ريحـان سـبز

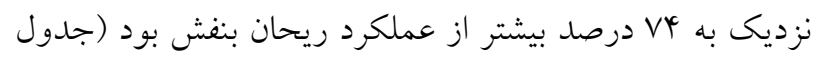

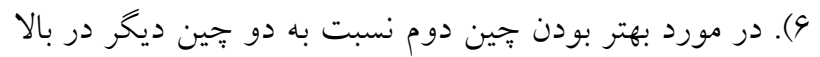

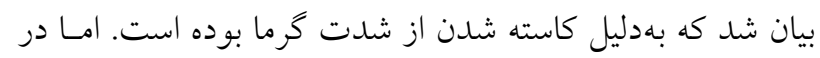
مورد تفاوت جشمكير عملكرد كل در بين دو رقم ريحان، شايد

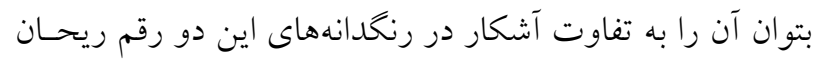
و كارايى بهتر ريحان سبز براى فتوسنتز نسبت داد.

\section{ظرفيت آنتى اكسيدانى}

ظرفيت بادأكسايندكى ريحان بهطور بسيار معنى دارى ( P

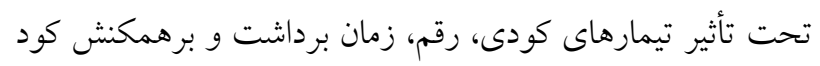

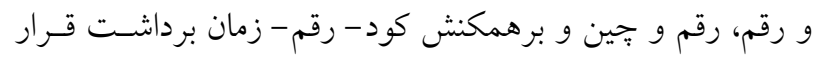

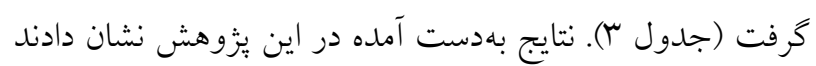

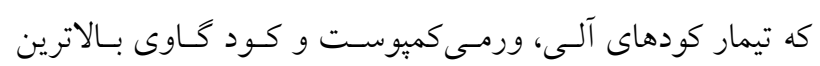

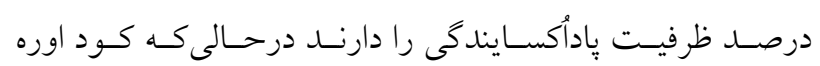

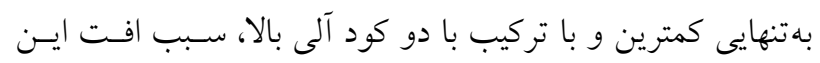

ريحان و افزايش شـاخ و بـرى آن اسـت. بنـابراين نتـايج ايـن

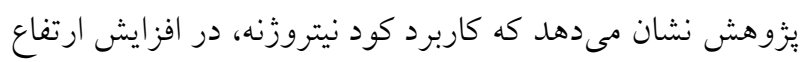

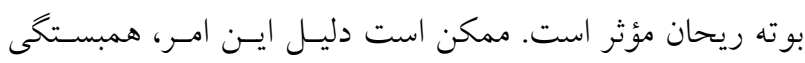

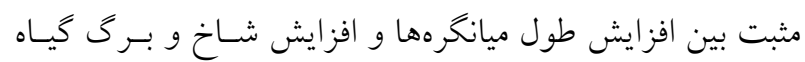

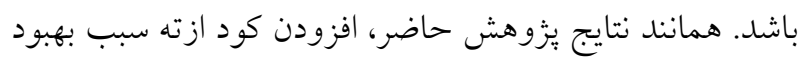

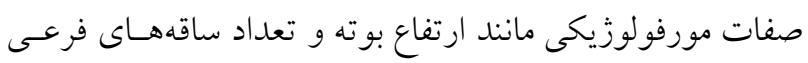

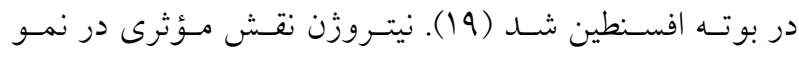

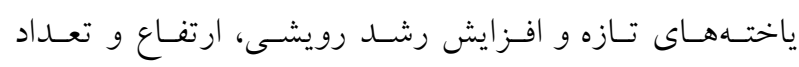

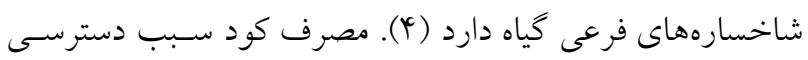

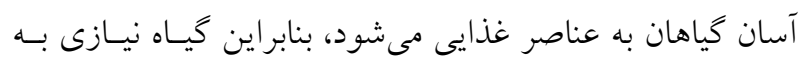

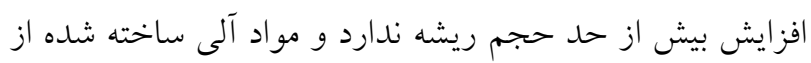

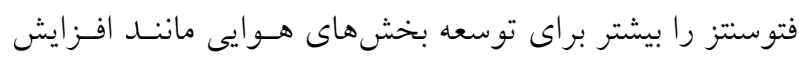
ارتفاع بو ته و تعداد شاخههاى فرعى مصرف مى كند (广).

\section{عملكرد تر كل اندام هوايى در هكتار}

عملكرد كل ريحان بهعنوان كاركردى از رشـــ انــامهـاى هـوايى

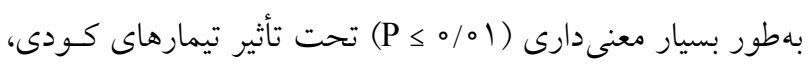

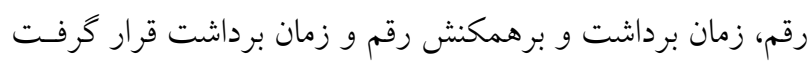

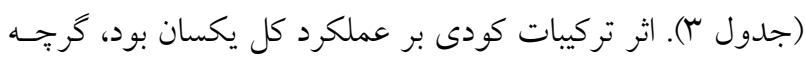

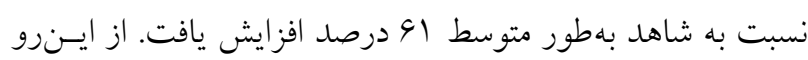

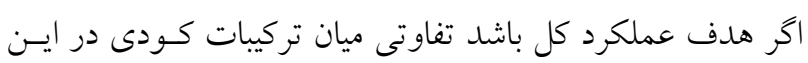

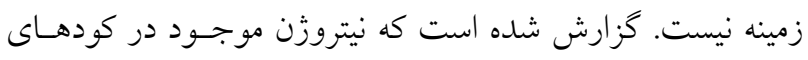

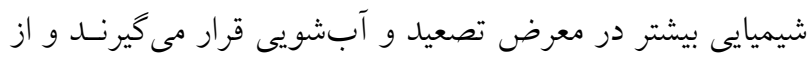

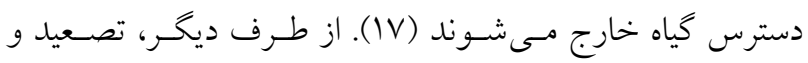

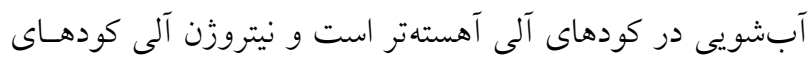

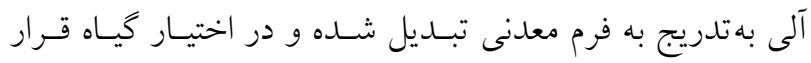

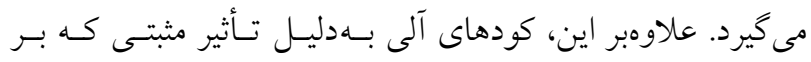

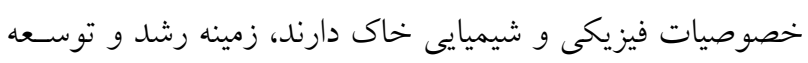

بيشترى را براى كياه فراهم مى كنند (YY).

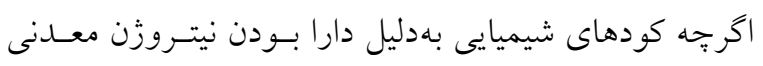

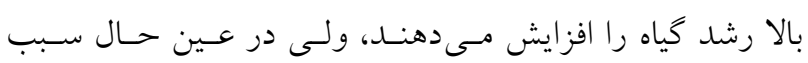

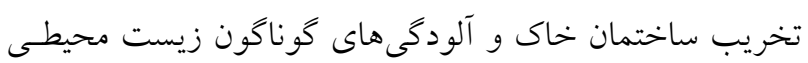


كيلو گرم) كمتـرين مقــار تجمـع نيتـرات را از خــود نشـان دادنـــ (جدول Y). بهطوركلى تيمارهاى كودى بهترتيب از بيشـترين مقـدار نيتـرات بـه كمتـرين مقـدار شـامل اوره > كـود كـاوى + اوره > ورمى كميوست + اوره > ورمى كميوسـت > كـود خـاوى > شـاهد بودند. افزون بر اين، از نظــر آمـارى اخـتلاف معنسى دارى ريحـان بنفش با ميانگين غلظت نيترات IVD/0 ميلى گــرم در كيلـو گرم با ريحان سبز با ميانكين غلظـت نيتـرات كيلو گرم داشـت (جـــول 9). ميـانخين غلظـت نيتـرات در بـين

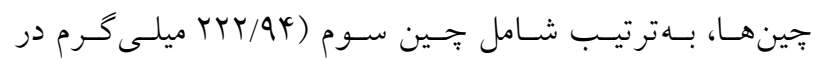

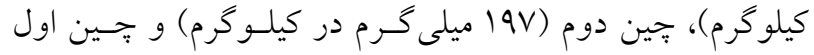

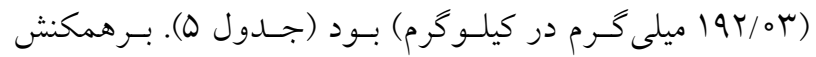
سه گانه زمان برداشت، كـود و رقـم بــراى مقـدار نيتـرات كيـاه معنى دار شد. كمترين مقدار نيترات گياه در تركيب هر سه زمـان برداشت با ريحان بنفش ديده شد و بين اين با تركيب تفاوتى از نظر آمارى وجود نداشت (جدول ^). در مورد برهمكنش زمـان برداشت و رقم، بيشترين مقدار نيترات در تركيب جين سـوم بـا ريحان سبز مشاهده شد (جدول ^).

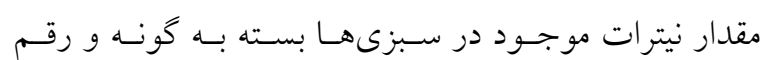

متفاوت است. بهعنـوان مثـال خـانو ادههـاى Chenopodiaceae و Poaceae Solanaceae,Brassicaceae تجمع نيترات بيشترى را نسبت به ساير كونههـا دارنـــ. عوامـل محيطى هم بر ميزان انباشت نيترات در گياهان اثر دارنـد. شـايد علت يايين بودن نيترات در زمان برداشت اول، بهدليل نور كافى يُ و مساعد بودن شرايط آبوهـوايى در ايسن مرحلـه از برداشـت ريحان باشد. امـا در زمـانهـاى برداشـت سـوم و دوم احتمـالاً بهدليل افزايش تعداد ساقهاى جانبى و بلند شدن ارتفاع بوتههـا بهخصوص در كياهان تيمار شده با كـود شـيميايى فضـاى بـين بوتهها كمتر شده كه اين باعـث كـاهش نـور و تجمـع نيتـرات بيشتر در كياهان شده است.

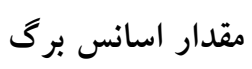
مقدار اسانس ريحان بهطور بسيار معنى دارى (
ويزگ گى شدهاند، به گونهاى كه نسبت به شاهد هم ظرفيت كمتـرى دارند (جدول \&). همجينين در مقايسه بـين رقـمهــا، رقــم ريحــان

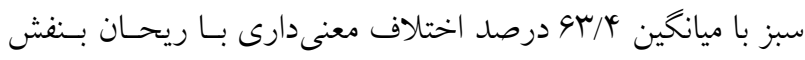
با ميانگين ك/ / هو درصد داشت (جدول ه). افزون بر اين، بيشـترين ميزان فعاليـت آنتـى اكسـيدانى در بـين زمـانهـاى برداشـت نيـز به ترتيب زمان برداشت دوم (VD/9 درصد)، زمان برداشت سـوم

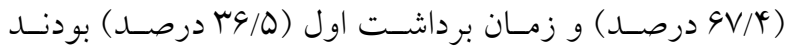
(جدول ه). برهمكنش فاكتورهاى سه گانه زمان برداشت، كود و رقم براى ظرفيت آنتى اكسيدانى معنى دار شد. بهترين تركيـبـهـا با زمان برداشت دوم با كودهاى ورمى كميوسـت، كـود كـاوى و كود كاوى + اوره با ريحان سبز بهدست آمـد (جـدولهـاى Vو و

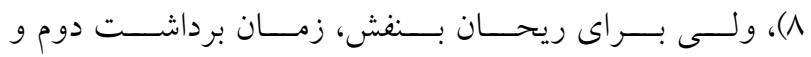
ورمى كميوست بهترين نتيجه را داد و بين اين ب تركيب تفـاوتى از نظر آمارى وجود نداشـت (جــدول ^). در آزمايشسى، ميـزان ظرفيت آنتى اكسيدانى ميوه فلفل (فعاليت آنتى اكسيدانى، فنل كل،

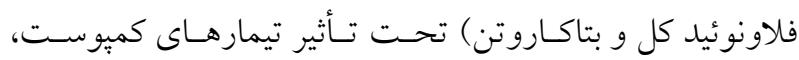
افزايش يافت (ها ). بنابراين براى افزايش ظرفيت آنتى اكسـيدانى

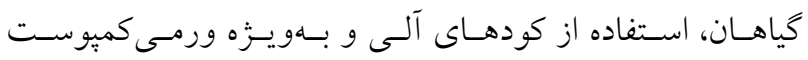
مى تواند سودمند باشد.

ميزان نيترات گیاه مقدار نيترات موجود در ريحان بهطسور بسـيار معنسىدارى (10/0

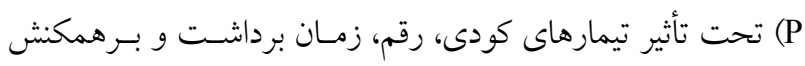
كود و رقم، رقم و جين، كود و جين و برهمكنش كود- رقم - زمان برداشت قرار گرفت (جدول ץ). آشكار است كه مقدار نيترات گيـاه كاركردى از مقدار كودهاى ازتهاى است كه به كيـاه داده مسىشـود. ميـانكين غلظـت نيتــات در ريحــان در تيمـار كـود اوره بـهـــور معنى دارى بيشتر از تيمارهاى ديخر بود (جدول †). غلظـت نيتـرات در تيمارهاى كود آلى همراه بــا اوره نيـز نسـبت بـهـ ديخــ تيمارهـا بيشتر بود و كمترين غلظت در تيمار كود كاوى و شـاهد بـهدسـت

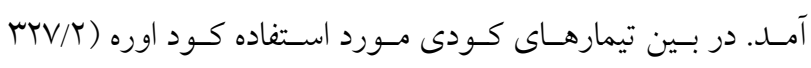
ميلى گرم در كيلوگرم) بيشترين و تيمار شـاهد (1/90 ميلى گـرم در 
نشد، ولى تمـامى آنهـا اخـتلاف معنسى دارى بـا شـاهد داشـتند

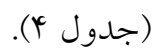
يافتهاى اين يـزروهش، اثـر مثبـت كـاربرد كودهــاى آلى و بهويزه ورمى كميوست را در كشت مزرعهاى گياه دارويى ريحان براى افزايش عملكرد و همجنين افزايش ظرفيت آنتى اكسـيدانى و كاهش تجمع نيترات نشان دادند. بنابراين بـا اسـتفاده از كـود كاوى و ورمى كميوسـت و كـاهش ميـزان اسـتفاده از كودهــاى شيميايى در كشت كياه دارويى ريحـان، مسى تـوان محصـولى بـا عملكرد قابل قبول و كيفيت بهتر توليـد نمـود. افـزون بـر نـوع كوددهى، در اين آزمايش، زمان برداشت و رقم ريحـان هـم بـر عملكرد و ويزّكىهاى كيفى ريحـان اتـر داشـتند. بهتـرين زمـان برداشت در اين آزمايش زمان برداشت دوم بود كه بهجز انباشت بيشتر نيترات در كياه، براى ساير صفات اندازهگيرى شده بهتر از دو زمان برداشت ديخر بود. همانطوركه اشاره شد، دليل اين امر مى تواند مربوط به شرايط بهينه آبوهوايى براى رشد گياه براى

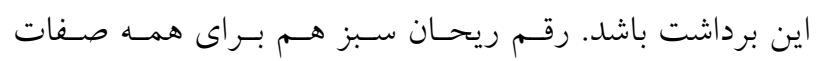
اندازهيرى شده بهتر از ريحان بنفش بود. در نتيجه، مجموعهاى از عوامل مانند نوع كوددهى، رقم و شرايط اقليمى مىتوانند بـر عملكرد و كيفيت محصول ريحان اثر بخذارند.
تأثير تيمارهاى كودى، رقم، زمان برداشت و بــرهمكنش كـود و

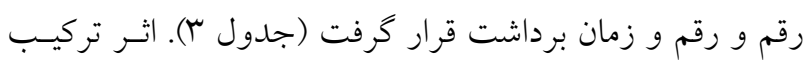

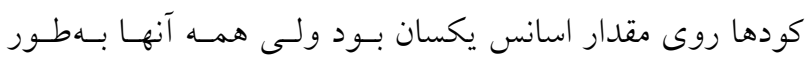

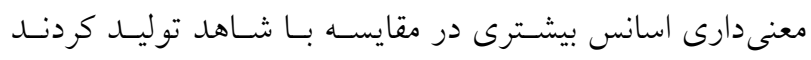
(جــدول †). مقــدار اسـانس در زمـان برداشـت دوم بــهــور معنى دارى بيشتر از دو جين ديخر بود و ¥جين سوم بهتر از جــين نخست بود (جدول ه). رقم هم روى مقدار اسانس اثر داشت و بالاترين مقدار اسانس در ريحان سبز بهدست آمد، به گونهاى كه اه درصد اسانس بيشترى نسبت به ريحان بنفش توليد مسى كنـد (جدول 9). در سطح احتمال ا درصد معنى دار شد، امـا اثـرات متقابل كـود × رقـم و زمـان برداشـت × كـود × رقـم معنسى دار نشدند. در بين تيمارهاى زمان برداشت اختلاف معنسىدار بـراى مقـدار اسـانس مشـاهده شــ (جـــول ه)، زمـان برداشـت دوم بيشترين و زمـان برداشـت اول كمتـرين مقـدار اسـانس را دارا بودند (جدول ه). در بـين دو رقـم مـورد آزمـايش هــم مقــدار اسانس ريحان سبز از نظـر آمـارى بـيش از ريحـان بـنفش بـود

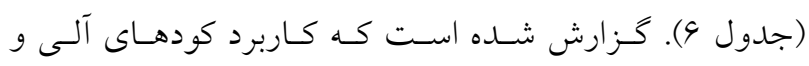
شيميايى بهدليل داشتن نيتـروزن و فسـفات در افـزايش اسـانس

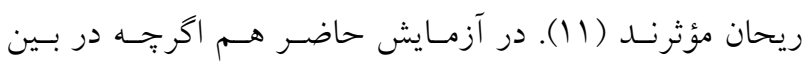

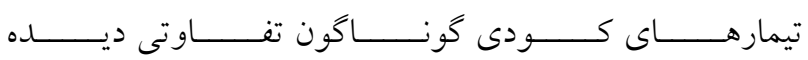

\section{منابع مورد استفاده}

1. Adediran, J. A., L .B .Taiwo. M. O. Akande. R. A. Sobulo and O. J. Idowu. 2004. Application of organic and inorganic fertilizer for sustainable maize and cowpea yields in Nigeria. Journal of Plant Nutrition 27:1163-1181.

2. Alizadeh, A., 2009. Selection of Optimal Culture Medium for Growing Organic Tomatoes and Cucumber Seedlings. Shiraz University, Shiraz, Iran. (In Farsi).

3. Amami, A. 1996. Plant Analysis Methods. vol. 1, Soil and Water Research Institute. Publication No. 982. Tehran, Iran. (In Farsi)

4. Aminifard, M. H., H. Aroiee. A. Ameri and H. Fatemi. 2012. Effect of plant density and nitrogen fertilizer on growth, yield and fruit quality of sweet pepper (Capsicum annum L.). African Journal of Agricultural Research 7:859-866.

5. Arancon, N., C. A. Edwards. P. Bierman. C. Welch and J. D. Metzger. 2004. Symbiotic microorganisms, a key for ecological success and protection of plants. Plant Biology and Pathology 327: 639-64.

6. Arguello, J. A., A. Ledesma, S. B. Nunez, C. H. Rodriguez and M. D. Goldfarb. 2006. Vermicompost effects on bulbing dynamics, non-structural carbohydrate content, yield and quality of 'Rosado Paraguayo' garlic bulb. HortScience 41: 589-592.

7. Azarmi, R., M. T. Giglou and R. D. Taleshmikail. 2008. Influence of vermicompost on soil chemical and physical properties in tomato field. African Journal of Biotechnology 7: 2397-2401.

8. Azizi, M., F. Rezvani, Z. K. M. Hassan, A. Lekzian and A. Nemati. 2009. Effects of vermicompost and irrigation on 
morphological traits and essential oil of chamomile. Iran. Journal of Medicinal Plants Research 24: 82-93.

9. Bachman, G. R. and J. D. Metzger. 2008. Growth of bedding plants in commercial potting substrate amended with vermicompost. Bioresource Technology 99: 3155-3161.

10. Bhattacharyya, P., K. Chakrabarti and A. Chakraborty. 2005. Microbial biomass and enzyme activities in submerged rice soil amended with municipal solid waste compost and decomposed cow manure. Chemosphere 60: 310-318.

11. Bromand, N. I., V. Marezi and M. Sadat Hossini Groh. 2011. Comparison the effect of organic and chemical fertilizers on yield and essential oil percentage of basil medicinal plant. In: Proceeding of the $7^{\text {th }}$ Iranian Horticultural Sciences Congress, Esfahan, Iran. (In Farsi).

12. Dadkhah, A., M. Amini Dahaghi and M. Kafi. 2012. Effects of different levels of nitrogen and phosphorous fertilizers on yield quantity and quality of Matricaria recutita L. Iranian Journal of Field Crop Research 10: 321326. (In Farsi).

13. Darzi, M. T., A. Ghalavand, F. Rejali and F. Sefidkon. 2006. Effects of biofertilizers application on yield and yield components in fennel (Foeniculum vulgare Mill.). Iranian Journal of Medicinal and Aromatic Plants 22: 276-292. (In Farsi).

14. Darzi, M. T., M. Haj Seyedhadi and F. Rejali. 2012. Effects of the application of vermicompost and phosphate solubilizing bacterium on the morphological traits and seed yield of anise (Pimpinella anisum L.). Journal of Medicinal Plants Research 6: 215-219.

15. Doroudian, H. R., A. Soltani nejad and A. Baghi zade. 2011. Effects of chemical fertilizers, organic matters and their combinations on watermelon. In: Proceeding of the $2^{\text {nd }}$ National Conference on Agriculture and Sustainable Development, Future Opportunities and Challenges. Shiraz, Iran. (In Farsi).

16. Ebrahimzadeh, M. A., F. Pourmorad and S. Hafezi. 2008. Antioxidant activities of Iranian corn silk. Turkish Journal of Biology 32: 43-49.

17. Erhart, E., F. Feichttinge and H. Hartl. 2007. Nitrogen leaching losses under crops fertilized with biowaste compost compared with mineral fertilization. Journal of Plant Nutrition and Soil Science 170: 608-614.

18. Ghanbari, Y. and H. Barqi. 2009. Stable development in agriculture sector: the main challenges. Rahbordeyas 16: 218-234. (In Farsi).

19. Gholami, M. and A. Azizi. 2006. The effect of nitrogen fertilizer on total essential oil and the amounts of a-thujone and chamazulene in wormwood (Artemisia absinthium L.) Agricultural Research (Water, Soil and Plants in Agriculture) 6: 83-93. (In Farsi).

20. Ghost, B. C. and R. Bhat. 1998. Environmental hazards of nitrogen loading in wetland rice fields. Environment and Pollution 102: 123-126.

21. Kandeel, A. M., S. A. T. Naglaa and A. A. Sadek. 2002. Effect of biofertilizers on the growth, volatile oil yield and Aroma profiles of five basil (Ocimum basilicum L.) cultivars grown under conventional and organic conditions. Food Chemistry 107: 464-472.

22. Kapoor, R., B. Giri and K. G. Mukerji. 2004. Improved growth and essential oil yield and quality in Foeniculum vulgare Mill on mycorrhizal inoculation supplemented with P-fertilizer. Bioresource Technology 93: 307-311.

23. Makizadeh Saghafi, M., S. Nasrolahzadeh, S. Zohtab Salmasi, M. Chichi and K. Khavazy. 2012. Effect of biofertilizers, organic and chemical fertilizers on quantitative and qualitative characteristics of basi (Ocimum basilicum L.). Journal of Agricultural Science 22: 1-12. (In Farsi).

24. Malekoti, M. J. 1996. Increasing Yield by optimizing fertilizer use in Iran in order to achieve sustainable agriculture. In: Proceeding of the $5^{\text {th }}$ Iranian Soil Science Congress. Karaj, Iran. pp.3. (In Farsi).

25. Marcote, I., T. Hernandez. C. Garcia and A. Polo. 2001. Influence of one or two successive annual applications of organic fertilisers on the enzyme activity of a soil under barley cultivation. Bioresource Technology 79: 147-154.

26. Norman, Q. and C. Arancon. 2006. Effects of humic acids from vermicomposts on plant growth. European Journal of Soil Biology 42: 65-69.

27. Soodaee Mashaee, S., N. Aliasgharzade, S. Ostan. 2008. Kinetics of nitrogen mineralization in soils amended with compost, vermicompost and cattle manure. Journal of Water and Soil Science 11(42): 405-414. (In Farsi).

28. Tahami, S. M. K., P. Rezvani Moghaddam and M. Jahan. 2010. Comparison the effect of organic and chemical fertilizers on yield and essential oil percentage of Basil (Ocimum basilicum L.). Agroecology 2: 63-74. (In Farsi). 


\title{
The Effect of Organic and Chemical Nitrogen Fertilizers on the Yield and Qualitative Characteristics of Two Basil Cultivars
}

\author{
M. Chezgi ${ }^{1}$, V. Chalavi ${ }^{2}$ and V. Akbarpour ${ }^{3}$
}

(Received: May 31-2016; Accepted: July 31-2017)

\begin{abstract}
Adding compost and vermicompost organic fertilizers to soil can improve soil physical conditions, nutrient elements and microorganisms. In the present study, the effect of the cow manure, vermicompost, and urea chemical fertilizer, alone or in combination, on the yield and qualitative characteristics of basil (Ocimuom basilicum L.) was investigated. The experiment was conducted as a split plot based on the complete randomized block design in 2013. The treatments included 6 levels of fertilizers as the main factor, and two green and purple basil cultivars as the sub factor; three harvest times were taken as the sub-sub factor. Dual treatments of organic fertilizers and urea, as compared with the organic fertilizers treatment alone, did not lead to any statistically significant increase in the yield of fresh and dry plants. However, the amount of nitrate in the plant organs was increased in the combination treatments of organic fertilizers with urea. Except for the amount of plant's nitrate, the green basil was better than purple one with regard to the antioxidant capacity, yield and vegetative traits. In terms of the harvest time, the highest yield and antioxidant capacity were observed in the second harvest. These results clearly showed the positive effect of the use of organic fertilizers on increasing the yield and quality of the basil plant. Therefore, according to the findings of this experiment, by using animal manure and vermicompost organic fertilizers, it is possible to lower the application of chemical fertilizers and prevent their harmful effects on the environment.
\end{abstract}

Keywords: Cow compost, Urea fertilizer, Antioxidant capacity, Nitrate, Cow vermicompost.

1, 2, 3. MSc. Student and Assistant Professors, Respectively, Department of Horticulture, Sari Agricultural Sciences and Natural Resources University, Mazandaran, Iran.

*. Corresponding Author, Email: v.chalavi@sanru.ac.ir 